\title{
THE GROWING IMPACT OF MARRIAGE
}

\author{
Ruut Veenhoven
}

\author{
Published in: Social Indicators research, 1983, vol 12, pp 49-63
}

\begin{abstract}
In present day Western society the institution of marriage appears to be of great significance for the well-being of the individual. Compared with married persons, the unmarried are generally less happy, less healthy, more disturbed and more prone to premature death. Among the married, happiness and health are highly dependent on marital success. The idea has been floated that the importance of marriage is now gradually declining. It is believed that single life is becoming more satisfying and that married persons are gradually becoming less dependent on their spouses.

Empirical data do not substantiate that belief. Firstly, the differences in well-being between unmarried and married persons are becoming greater rather than smaller. In the Netherlands between 1950 and 1980 - suicide rates have risen far more among the unmarried than among the married. Furthermore the differences in happiness between unmarried and married persons appear greatest in the most modern European countries, whereas almost no differences exist in the most traditional ones. Secondly, married person' appear to have become more dependent on the relationship with their spouse rather than less. During the last few decades in the Netherlands the overall happiness of married people has become more closely associated with their satisfaction with marriage. These trends can be interpreted as suggesting that marriage is becoming an increasingly indispensable 'haven' in an increasingly 'privatizing' world.
\end{abstract}

\section{INTRODUCTION}

All social institutions affect individual well-being, but not all affect it to an equal degree. In the modern Western world, marriage is a relatively important institution. It has been shown that individual well-being in modern Western society is highly dependent on the presence of a marital relationship and on its quality.

The significance of the marital relationship has been documented in various investigations that have compared the well-being of married and unmarried persons. First of all it has been shown that unmarried persons are less happy on average. See for example Gurin et al. (1960, p. 232). Bradburn ( 1969, p. 149-154), Campbell et al (1976, Ch. 3), Andrews and Withey (1976, Ch. 5), and Wilkening and McGrahanan (1978). Secondly the unmarried have been seen to suffer more from psychological disturbances (Gove, 1972a). to be in poorer physical health (Verbrugge. 1979 ) and to be more prone to suicide (Gove, 1972b). Consequently the mortality rate is higher among unmarried people. (Gove, 1973; Kobrin and Hendershot (1977). These differences have 
been observed in several industrialized nations. See for example Gove (1972b), Lynch (1977, p. 243), Koskenno (1979), and Danigelis and Pope (1979). Typically the following hierarchy of well-being appears: at the bottom the divorced. then the widowed, next, at a distance, the never married, and the married at the top. The differences are generally more pronounced among males than among females and greater among young adults than among elderly persons.

The evidence for the importance of the quality of marriage is less rich, but no less conclusive. Firstly, several investigations have shown that the overall happiness of married people is highly related to their satisfaction with their marriage. See for example Veroff (1962, p. 196), Bradburn (1969, p. 153), Glenn (1975, p. 597) and Andrews and Withey (1976, p. 156). Recently Glenn and Weaver ( 1931) have demonstrated that no domain satisfaction is so closely related to overall happiness as satisfaction with marriage. These latter investigators have also shown that a poor marriage gives even more unhappiness than no marriage at all (p. 165). Secondly, a high degree of satisfaction with one's marriage has been shown to go hand in hand with good physical health (Weis and Aved, 1973. p. 1382) and with a low incidence of psychiatric complaints (Kooy, 1975, p. 183). In this context Haavio-Manilla (1971, p. 591) once observed that no other social institution affects individual life satisfaction to such an extent as marriage.

\section{THE PROBLEM}

This is how things are today. But will it always stay that way? Several social prophets believe it will not; they feel that marriage will lose its impact; in particular they believe that living alone is becoming a more attractive alternative and that married people are gradually becoming less vulnerable to problems with their spouse. In support of this view they refer to the growing number of single households in western nations and to the rising divorce rates. This idea of a diminishing utility of marriage is widely spread. Its growing popularity is illustrated by a change in public opinion in the Netherlands. In $1965,60 \%$ of the Dutch population still agreed with the statement that 'unmarried people are generally less happy than married people of the same age'; in 1975 , only $35 \%$ did so (SCP, 1976). Is marriage really becoming less crucial for individual wellbeing? Data about trends in single living and divorce cannot answer that question convincingly. What we need is data on timetrends in the above mentioned relationships. Curiously such data have not been provided as yet. Though a lot has been written about the relation between marriage and well-being, there are no reports about change and stability of this relation through time.

\section{DATA}

Data on timetrends in the relationship between marriage and well-being are scarce. The few I found come largely from the Netherlands. They concern changes in the difference between married and unmarried people with respect to suicide and happiness. The first come from official suicide records, the latter are derived from reports on empirical happiness studies. I also found a recent cross-national investigation which allows a comparison of the relative happiness of married and unmarried persons in modern and more traditional European nations. Finally some investigations in the Netherlands allow a look on the impact that marital quality had on the overall happiness of married people during the last decades. The facts can be summarized as follows. 


\subsection{Suicide Rose More Strongly Among the Unmarried Than Among the Married in the}

\section{Netherlands}

As in other industrialized countries, the level of suicide among the unmarried is relatively high in the Netherlands. Similar to other industrialized nations the suicide rates have also risen during the last few decades. If it is true that single life is becoming relatively more satisfying, we might expect that the increase would be smaller among unmarried persons than among the married. This is clearly not the case. As can be seen in the figures, suicide rose much more among the unmarried: at least among divorced and never-married people.

Scheme 1 shows suicide rates among males. Among divorced males the number of suicides per 100000 has increased 22 times as much as among married males; regression coefficients are respectively +0.10 and +2.25 . Among never-married males suicide increased almost five times as much; the regression coefficient is +0.46 . The figure of widowed males does not show such a relative increase. In fact, the increase is somewhat less pronounced than among the married males. The regression coefficient of the increase in this category is +0.05 .

Scheme 2 shows a similar trend among females. The differences are less pronounced however. Compared with married females, suicide among divorced females rose nearly ten times as much; regression coefficients are respectively +0.08 and +0.76 . Among never-married females the rise is nearly four times greater (regression +0.29 ). Again the widowed are the exception. Actually the suicide rate has dropped somewhat among widows. The regression coefficient is -0.09 .

This baffling rise in the suicide rates among divorced and never-married people cannot he explained as a result of changes in age composition of the marital categories 1) or by growth in number of concubinages in the period at hand 2). It is worth mentioning that in the USA single life seems to have become riskier as well during the last few decades. Carter and Glick (1970, p. 342) have observed that between 1940 and 1960 mortality rates have dropped among the married but have remained unchanged among the unmarried.

\subsection{The Unmarried Became Relatively Less Happy in the Netherlands}

A similar trend has showed up in self reports of happiness. In 1948 unmarried people in the Netherlands did not report less satisfaction with life than married people (NIPO, 1949, p. 4). In the decades that followed, the general level of happiness has sharply risen in the Netherlands. It rose more among the married than among the unmarried; in 1970 married people appeared clearly more happy than unmarried ones (Bakker. 1974, p. 15).

In the USA no such rise in happiness has occurred during this period. However, the difference in happiness between married and unmarried persons has grown as well; especially the difference in happiness between married and never-married persons. In 1946 this difference equaled $(G=+0.28$ (Wessman, 1956, p. 190), while in 1957 it had risen to $G=+0.41$ (Gurin et al., 1960, p. 233).

Some doubts have been expressed about the validity of the self report concerned here. Responses to questions about the subjective appreciation of life would be biased by, among other things, stereotypes about the good life, social desirability effects and defensive denial. Efforts to demonstrate these doubts empirically have been largely unsuccessful however (Veenhoven, in preparation, Ch. 3), Moreover, these doubts are hardly relevant in this discussion on time trends in differences. Response bias can be misleading only if it works out differently among the married than among the unmarried and if it has become more frequent in one category than in another. I do not see reasons to assume so. 


\subsection{Marital Satisfaction and Overall Happiness Became More Strongly Associated in the Netherlands}

Among the married, the significance of marriage can be measured by the statistical association between marital satisfaction and overall happiness. The greater the association between these variables, the greater the impact of marriage probably is. If it is true that marriage is losing its impact on individual well-being, we might expect that the association between these variables would have dropped during the last few decades. Yet, here again, this appears not to be the case.

Scheme 3 presents the results of four surveys on samples more or less representative of the Netherlands' population. These studies used almost identical questions on marital satisfaction and overall happiness. For each investigation the association between these two variables has been computed. The data show two trends: first there is an absolute increase in the association between marital satisfaction and happiness. The level of association rose from +0.40 to +0.73 . Secondly a relative increase can he observed. When compared with associations of overall happiness to other domain satisfactions, the association with martial satisfaction becomes greater as time goes by. For example, in 1949 'satisfaction with job' was still the best predictor for overall-happiness. In 1966 'satisfaction with marriage' had taken its place. Similarly we can see that the relationship of 'satisfaction with health' to overall happiness has remained stable though time, while the association of 'satisfaction with marriage' to overall happiness has increased. These data do not suggest that marriage matters less to modern people. Rather they indicate that married people are becoming more dependent on the quality of the relationship with their spouse.

Unfortunately it is not possible to check whether such a trend has also occurred in the USA. Though many happiness investigations haven been performed in that country in the postwar decades, none of the earliest ones has related happiness to marital satisfaction.

\subsection{In the Most Modern European Nations the Unmarried are Relatively Most Unhappy}

If it is true that progress is freeing us from the traditional dependency on marital relations, we might expect that marriage at the present time would be a dispensable commodity in the most advanced cultures. More specifically we might even expect that the differences in well-being between married and unmarried people would be smaller in 'modern' nations than in 'traditional' ones.

In this context a recent cross-national survey in the European Community (Commission, 1975) is of interest. 3) Representative samples in all EC-countries were questioned about happiness. The results are presented in Scheme 4. Again they show clear differences between marital status categories. These differences are not equally great in the various countries. Contrary to the prediction, they are greatest in the most modern nations: in Denmark and in the Netherlands. Almost no differences can be found in the two most traditional nations: in Ireland and in Italy. 4) This does not suggest that the relatively deprived position of the unmarried is a rudiment of a passing phase in the development of industrial societies. The data rather indicate that the lower well-being of unmarried persons is a product of modernization.

\section{DISCUSSION}

Let me begin with the growing differences in well-being between married and unmarried persons. Traditionally there are three explanations for the relatively low well-being of the unmarried : the 'labeling hypothesis', the 'selection hypothesis' and the 'protection hypothesis'. The 'labeling' explanation claims in essence that unmarried people are regarded as unhappy and hence feel unhappy. The 'selection' explanation is that happy and healthy people are more likely to find a partner. The 'protection' theory holds that people need intimate relationships, especially 
relationships with a spouse at children, which provide satisfaction in the realm of affection, identity, meaning and care and which keep them away from risky behaviors and suicidal impulses. There is some truth in all these theories. See for example Gove ( 1973). Here the question is whether they can also explain the recent widening of the gap between the married and the unmarried.

The 'labeling' hypothesis clearly does not account for it all. Public opinion about unmarried life has become more favorable during the period concerned; in particular the traditional rejection of divorced people has made place for fairly general acceptance. Note that Scheme 3 shows that divorced people are at the present time relatively worst off in the most enlightened European countries. If 'labeling' had any effect at all on well-being, it must have counterweighted an even greater deterioration in the life quality of the unmarried. The 'selection' hypothesis does not offer an explanation either There is no reason to believe that the unmarried part of the Dutch population contains more 'misfits' now than it did twenty years ago. The percentage of married persons in the population has hardly risen, hence a more stringent selection is not likely to have occurred. On the contrary, the number of divorced people has risen dramatically. In this category an overrepresentation of 'misfits' is more likely to have decreased than to have augmented.

This leaves us with the 'protection' hypothesis. In the context of this theory two more specific explanations can be suggested. The first 'protection explanation' is that the unmarried have become more vulnerable because more of them live alone. Remember that the theory stresses the significance of 'intimate' relations, not necessarily 'marital' relations. Sharing a household with relatives or friends can provide a 'protection' similar to that of marriage. In supporting this view Kobrin and Hendershot (1977) have shown that the mortality rate is higher among unmarried persons who live alone than among unmarried persons who live with their parents or siblings. It is indeed true that the number of single households has risen in the Netherlands during the period at hand. Between 1960 and 1971 the percentage has increased from $12 \%$ to $17 \%$ (Beukens-De Vries. 1978). A second explanation could be that singles may have become more isolated in another sense as well. The ongoing trend towards 'privatization' may have curtailed the amount and quality of outside social contacts for single people. Contacts with neighbors and family members seem to have decreased and contacts on the job seem to have become less personal and affectionate. Possibly social life in pubs and clubs has become somewhat more distant as well. This second variant of the protection theory ties in with several theories about longer historical developments in the Western world; for example with the notion that society developed from 'Gemeinschaft' to 'Gesellschaft' (Tonnies, 1887), with the theory that the family has become a 'haven in a heartless world' (Lasch, 1977) and with the idea that public life has grown less satisfying (Sennet, 1976). In the context of this explanation it is not so strange that in Italy and Ireland unmarried people are not less happy than the married ones. In these countries, public life is still more flourishing and the family network holds a greater sway. Unfortunately solid empirical indicators of the 'warmth' of outside social relations are difficult to come by. Hence this explanation must remain speculative.

So far, the protection hypothesis seems to explain the decreasing relative well-being of the unmarried reasonably well. There is one great problem however. It does not account for the fact that the suicide rate of the widowed has not risen. If the protection of marital relations has indeed become more indispensable, the widowed should have become more deprived as well. This discrepancy may be a matter of age. The widowed are mostly older people and among the elderly suicide has not increased in the Netherlands in the period between 1955 to 1978. The rise is concentrated in the age-category of 20 to 50. This leaves us with the question of why marriage 
should be having a greater impact on young and middle-aged adults than on the elderly. Several suggestions can be made. First it could be that the elderly are less dependent on public life, because they can draw on relationships formed earlier with family, children and friends. Secondly it is also possible that the elderly live in a 'warmer' subculture. The fact that retired people have lots of free time may stimulate the development of a network of acquaintances and friends. Thirdly it is not improbable that elderly people do not need intimate contacts that much, some may rather tend to 'disengage' (Cummings and Henry, 1961). Finally, loneliness is perhaps more bearable for elderly people. This might be so because it is regarded as a normal condition of life or because release by death is perceived to be near.

Next, the observed change among married persons: why has the quality of marriage become more significant for individual well-being? Here the same explanation can be applied as the one proposed for the decreasing well-being of unmarried people. When outdoor social contacts became more scarce and superficial, married persons must have become more dependent on their spouses. The fewer the relational alternatives available, the more vulnerable one is for marital problems.

However, there are other interpretations for the observed increase in the association between marital satisfaction and overall happiness. Overall happiness can be seen as the causal agent rather than marital satisfaction. For example, several studies have shown that happy people are generally less neurotic than unhappy people (see Gurin et al., 1960), and that neurotic people have a smaller chance of establishing a successful marriage (Kooy 1975, p. 183). Thus the growing association between marital satisfaction and overall happiness can equally well be taken to indicate that a satisfying marriage has come to require more competence on the part of the spouses. In other words: that marriage has become more problematic during the last few decades. This interpretation fits in well with the fact that divorce rates have increased steadily in the Netherlands during this period.

This alternative interpretation is not incompatible with the earlier tenet that marriage is becoming more indispensable. The growing importance of marriage may have made marital living more difficult. The ever greater monopoly of marriage as the source of affection and belongingness seems at least partly responsible for its internal problems. It may have forced marriage on to people who were in fact better suited to the single life. It is not unlikely either that the reduced significance of outdoor social contacts has caused the spouses to place higher demands on each other.

\section{CONCLUSION}

Suicide rates among divorced and never-married persons have risen sharply during the last two decades in the Netherlands. During the same period the overall happiness of married people has become more closely related to their satisfaction with marriage. Furthermore, a cross-national investigation in the EC-countries shows that unmarried persons are relatively the worst off in the most modern nations. These data indicate a growing impact of marriage on individual well-being. As such they contradict the modish opinion that marriage is losing ground. In fact, marriage seems to be more indispensable than ever. 


\section{NOTES}

1 If the average age of divorced and never-married persons had risen during the period under review, the rising rates of suicide would at least be partly explained, suicide being more frequent among the elderly than among the young. However, such a change in age composition is hardly noticeable. The average age of the divorced has in fact dropped somewhat.

2 In 1950 the number of concubinages in the Netherlands was negligible. At present 7\% of the Dutch households consist of concubinages (De Hond, 1978). Though this development parallels the observed rises in suicide I cannot imagine that there is a causal effect. I think that informal marriage 'protects' people as much as formal marriage.

Consequently there are no differences in happiness between 'married' and 'living as married' in Scheme 3. In fact it is more likely that the growth in the number of the concubinages in the Netherlands veils a greater rise of suicide among the really single.

3 Based on a re-analysis of the original data. The first report (Commission, 1975) contains some mistakes.

4 There are several more or less differing conceptualizations of 'modernity', stressing different aspects such as economic development. educational level, specific value patterns and psychological differentiation. In the realm of marriage, 'modernity' has been conceptualized as, for example, freedom of choice of partner, nuclearization of the family, equality of spouses and family planning. It would take too long to consider all countries on all these different aspects. Let it suffice to note that Italy and Ireland appear as most traditional on almost all counts and Denmark and the Netherlands as relatively modern.

\section{BIBLIOGRAPHY}

Andrews, F. M. and Withey, S. B. (1976)

Social Indicators of Well-Being

Plenum, New York.

Bakker, P. and Van de Berg, N. (1974)

Determinanten van geluk,

unpublished thesis, Erasmus University of Rotterdam.

Beuckens-De Vries, M. (1978)

Vormen van gezin en huishouden,

in: Corver C. J. M. et al: Gezin en Samenleving (van Gorkum, Assen), pp. 91 - 105.

Bradburn. N. (1969)

The Structure of Well-Being

Aldine, Chicago. 
Campbell, A. Converse P. E. and Rodgers W. L. (1976)

The Quality of American Life

ISR, Ann Arbor.

Carter, H. and Click P. C. (1970)

Marriage and Divorce: A Social Economic Study,

American Public Health Association. Vital and Health Statistics Monograph (Harvard University

Press, Cambridge, Mass.).

C.B.S.

Gerechtelijke Statistiek (1959 tot 1979)

Cumming, E. and Henry W E. (1961)

Growing old: The Process of Disengagement

Basic Books, New York.

Glenn, N. D. (1975)

The contribution of marriage to the psychological well-being of males and females, Journal of Marriage and the Family 37, pp. 594 - 601.

Glenn, N.D. \& Weaver C. N. (1981)

The contribution of marital happiness to global happiness, Journal of Marriage and the Family 43, pp. 161 - 168.

Gove, W. A. (1972a)

The relationship between sex roles, marital roles and mental illness,

Social Forces 51, pp. 34 - 44.

Gove, W A. (1972b)

Sex, marital status and suicide,

Journal of Health and Social Behavior 13, pp. 204 - 213.

Gove, W. A. (1973)

Sex, marital status and mortality,

American Journal of Sociology 79, pp. 45-67.

Gurin,G.,Veroff,J. and Feld, S. (1960)

How Americans View Their Mental Health

Basic Books, New York.

Haavio-Manilla, E. (1971)

Satisfaction with Family, Work, Leisure and Life, Among Man and Woman

Human Relations 24, pp. 585 - 601.

De Hond, M. (1978)

Onderzoek Huisvesting Alleenstaanden en Tweepersoonshuishoudens

Cebeon, Amsterdam. 
Kobrin, F. E. and Hendershot, G. E. (1977)

Do Family Ties Reduce Mortality? Evidence from the United States 1966- 1968

Journal of Marriage and the Family 39, pp. 737 - 745.

Kooy. G. A. (1975)

Seksualiteit. Huwelijk en Gezin in Nederland

Van Loghem Slaterus. Deventer.

Lasch (1977)

Haven in a Heartless World

Basic Books, New York.

Lynch. J. J. (1977)

The Broken Heart: The Medical Consequences of Loneliness

Basic Books, New York.

McKennel, A. (1973)

Cognition and Affect in Judgement of Subjective Well-Being

lnstitute for Social Research, London.

Mooser-Peeters, C. J. M. (1969)

Achtergronden van Geluksgevoelens

TNO/NIPG, Leiden.

NIPO (1949)

Wat de mensen gelukkig maakt

Publieke Opinie, 3, pp. 3 - 4.

Philips (1969)

De Nederlandse Huisvrouw

Philips Nederland N.V., Eindhoven.

SCP (1976)

Sociaal Cultureel Rapport

Sociaal Cultureel Planbureau, Den Haag.

Sennet, R. (1976)

The Fall of Public Man

Cambridge University Press, London.

Veenhoven, R. (1984)

Conditions of Happiness.

Reidel, Dordrecht

Verbrugge, L. M. (1979)

Marital status and health,

Journal of 'Marriage and the Family 41, pp.267-285. 
Veroff, J., Feld. S. and Gurin, G. (1962)

Dimensions of subjective adjustment,

Journal of Abnormal Psychology 64, pp. 195-205.

Wessman, A. E. (1956)

A psychological inquiry into satisfaction and happiness, unpublished Ph.D. Dissertation, Princeton University.

Wilkening, E.. A. and McGrahanan, D. (1978)

Correlates of subjective well-being in Northern Wisconsin, Social Indicators Research 5, pp. 211 - 234. 


\section{Scheme 1}

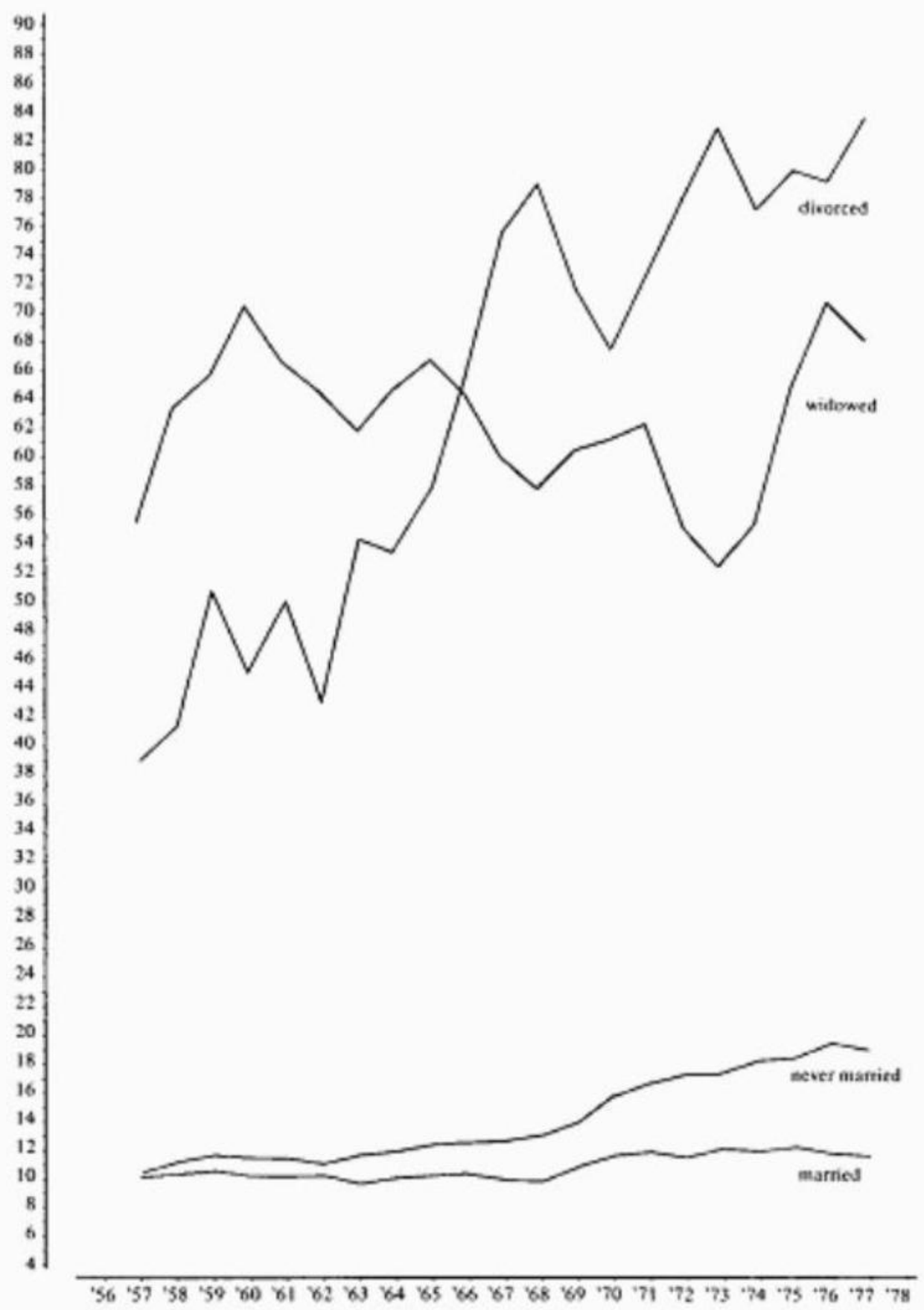

Suicides per 100000 males of 15 years and older between 1956 and 1978 in The Netherlands. 
Scheme 2
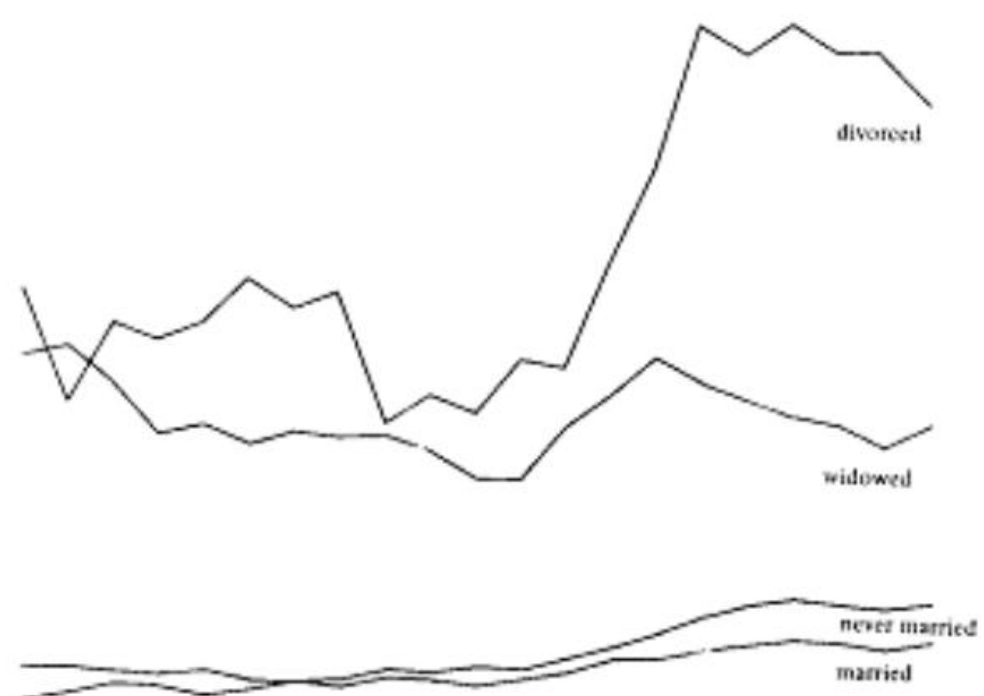

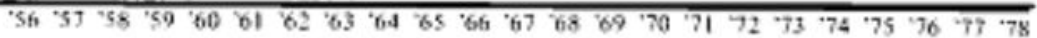

Suicide per 100000 females of IS years and older between 1956 and 1978 in The Netherlands. 
Scheme 3

Happiness by marital satisfaction in four surveys in the Netherlands between 1948 and 1970

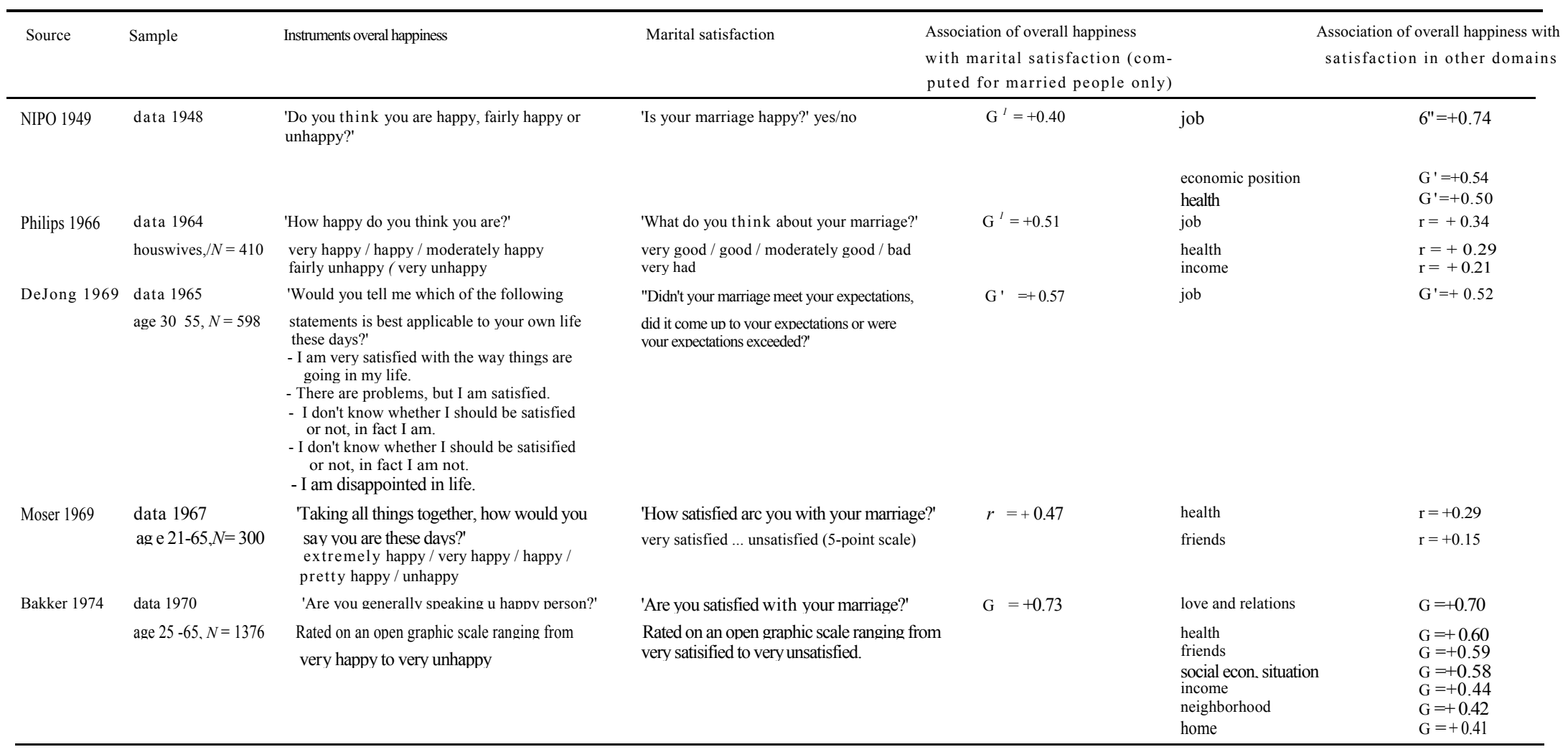

$\mathrm{G}^{l}=$ Gamma values computed by the present author on basis of frequency distribution in the original reports. 
Scheme 4

THE GROWING IMPACT OF MARRIAGE

Happincss by marital status in nine Western-European nations in May, 1975

Married Living as Never Divorced/ Widowed All married married separated

\begin{tabular}{|c|c|c|c|c|c|c|c|}
\hline \multirow[t]{4}{*}{ FRANCE: } & $N$ & 860 & 16 & 180 & 33 & 74 & 1163 \\
\hline & very happy & 16 & 31 & 17 & 9 & 11 & 16 \\
\hline & pretty happy & 59 & 44 & 51 & 27 & 47 & 56 \\
\hline & not too happy & 25 & 25 & 32 & 64 & 42 & 28 \\
\hline UNITED & $N$ & 923 & 4 & 229 & 26 & 129 & 1311 \\
\hline \multirow[t]{3}{*}{ KINGDOM: } & very happy & 23 & 25 & 18 & 12 & 20 & 22 \\
\hline & pretty happy & 50 & 25 & 56 & 46 & 47 & 50 \\
\hline & not too happy & 27 & 50 & 26 & 42 & 33 & 28 \\
\hline WESTERN & $N$ & 612 & 11 & 197 & 37 & 109 & 966 \\
\hline \multirow[t]{3}{*}{ GERMANY: } & very happy & 14 & 18 & 10 & 5 & 5 & 12 \\
\hline & pretty happy & 69 & 55 & 68 & 60 & 50 & 66 \\
\hline & not too happy & 17 & 27 & 22 & 35 & 45 & 22 \\
\hline \multirow[t]{4}{*}{ ITALY: } & $N$ & 629 & 2 & 312 & 10 & 69 & 1022 \\
\hline & very happy & 5 & 0 & 7 & 0 & 7 & 6 \\
\hline & pretty happy & 52 & 0 & 49 & 20 & 32 & 49 \\
\hline & not too happy & 43 & 100 & 44 & 80 & 61 & 45 \\
\hline THE & $N$ & 790 & 8 & 110 & 17 & 96 & 1021 \\
\hline NETHER- & very happy & 38 & 25 & 23 & 6 & 10 & 33 \\
\hline \multirow[t]{2}{*}{ LANDS: } & pretty happy & 55 & 50 & 68 & 47 & 61 & 57 \\
\hline & not too happy & 7 & 25 & 9 & 47 & 29 & 10 \\
\hline \multirow[t]{4}{*}{ DENMARK: } & $N$ & 678 & 70 & 154 & 24 & 65 & 991 \\
\hline & very happy & 45 & 39 & 37 & 21 & 21 & 41 \\
\hline & pretty happy & 52 & 53 & 52 & 46 & 65 & 53 \\
\hline & not too happy & 3 & 8 & 11 & 33 & 14 & 6 \\
\hline \multirow[t]{4}{*}{ BELGIUM: } & $N$ & 969 & - & 356 & 34 & 154 & 1513 \\
\hline & very happy & 40 & - & 38 & 18 & 19 & 37 \\
\hline & pretty happy & 53 & - & 53 & 50 & 55 & 53 \\
\hline & not too happy & 7 & - & 9 & 32 & 26 & 10 \\
\hline LUXEM- & $N$ & 191 & - & 81 & 5 & 29 & 306 \\
\hline \multirow[t]{3}{*}{ BOURG: } & very happy & 29 & - & 21 & 60 & 7 & 25 \\
\hline & pretty happy & 52 & - & 59 & 0 & 48 & 53 \\
\hline & not too happy & 19 & - & 20 & 40 & 45 & 22 \\
\hline \multirow[t]{4}{*}{ IRELAND: } & $N$ & 581 & - & 334 & 6 & 72 & 993 \\
\hline & very happy & 17 & - & 17 & 0 & 12 & 17 \\
\hline & pretty happy & 52 & - & 55 & 50 & 57 & 53 \\
\hline & not too happy & 31 & - & 28 & 50 & 31 & 30 \\
\hline \multirow[t]{4}{*}{ ALL: } & $N$ & 6233 & 111 & 1953 & 192 & 797 & 9286 \\
\hline & very happy & 26 & 33 & 21 & 12 & 13 & 24 \\
\hline & pretty happy & 55 & 50 & 55 & 44 & 52 & 54 \\
\hline & not too happy & 19 & 17 & 24 & 44 & 35 & 22 \\
\hline
\end{tabular}

Happiness was measured by the question: 'Taking all things together, how would you say things are these days - would you say you are very happy, pretty happy or not too happy?' Data provided by the Belgian Archives for the Social Sciences (BASS), Louvain-la-Neuve, Belgium. 